\title{
Article \\ Effects of the Traditional Mediterranean Diet in patients with otitis media with effusion
}

\author{
Calatayud-Sáez FMํㅜ, Calatayud B², Calatayud A³. \\ ${ }^{1}$ Pediatrician at the Child and Adolescent Clinic "La Palma". E-mail: altayud@gmail.com \\ 2 Nutritionist at the Child and Adolescent Clinic "La Palma". E-mail: \\ blanca.calatayud@gmail.com \\ ${ }^{3}$ Nurse and nutritionist at the Child and Adolescent Clinic "La Palma". E-mail: \\ anacalatayud94@gmail.com
}

Clinic and department completing the study: Child and Adolescent Clinic "La Palma", C/ Palma 17, bajo A, Ciudad Real, 13001. Castilla la Mancha. Spain.

Author for correspondence: Fernando M. Calatayud-Sáez. Child and Adolescent Clinic "La Palma". C/ Palma 17 Bajo A, 13001 Ciudad Real, Spain. Telephone: +34 626612313 E-mail: altayud@gmail.com, Twitter: @pednutricional

Abstract: Introduction: Otitis media with effusion (OME) is common in pediatric primary care consultations. Its etiology is multifactorial, although it has been proven that inflammation factors mediate and that immunity is in a phase of relative immaturity. The objective of this study was to assess the effects of the Traditional Mediterranean Diet (TMD) modulating inflammation and immunity in patients diagnosed with OME.

Materials and Methods: A prospective before-follow-up comparison study was conducted on 40 girls and 40 boys between 18 months and 5 years old. Tympanometry normalization was the main test to control the benefit of diet. Clinical and therapeutic variables were studied through evaluation questionnaires, a quality test of the diet as well as anthropometric parameters.

Results: At the end of one year, tympanometry had normalized in $85 \%$ of patients. The remaining $15 \%$ had normal audiometry and/or associated symptoms had decreased. Likewise, episodes of recurrent colds decreased from $5.96 \pm 1.41$ to $2.55 \pm 0.37$; bacterial complications of $3.09 \pm 0.75$ to $0.61 \pm 0.06$ and persistent nasal obstruction of $1.92 \pm 0.27$ to $0.26 \pm 0.05$. The degree of satisfaction of the families with the program was very high.

Conclusions: The application of the Traditional Mediterranean Diet has promising effects in the prevention and treatment of otitis media with effusion.

Keywords: otitis media with effusion, acute otitis media, rhino-sinusitis, Mediterranean diet, nutritional intervention.

\section{Introduction}


Otitis media with effusion (OME), also called otitis media serosa, oto-tubaritis or otitis media with chronic exudate is a chronic inflammation of the middle ear characterized by the presence of a fluid buildup in the middle ear space, in the absence of acute inflammation [1,2]. It is a very common disease in childhood, with $80 \%$ of children being considered to have experienced it at some point at the age of four. At three years, prevalence is estimated between 10-30\% of children. Its most common symptom is mild lytebypass hearing loss, which goes unnoticed by parents and is not easy to detect by the pediatrician in the absence of tympanometry devices [3,4]. Otoscopy can make an approximation to the diagnosis. However, otoscopy is not sensitive enough to detect many cases of OME[5]. It is a subject of controversy if prolonged hearing loss in childhood, right at the learning age of the vernacular, could negatively influence the child's proper educational development.

Although OME has a benign evolution, with a high percentage of spontaneous healing, the therapeutic attitude is currently aggressive, with a tendency to use drugs in a prolonged manner and to surgical intervention. The effectiveness of drug treatment is poor; includes the use of decongestants, antihistamines, oral and intra-nasal corticosteroids and antibiotics for which little clinical benefits was found, but of an increase in side effects [6]. Self-insorwing techniques with insufficient results have also been described [7]. The American Academy of Pediatrics recommends monitoring these children; if the duration of the thundering is longer than three months and hearing loss is longer than $40 \mathrm{~dB}$, recommends the introduction of ventilation tubes [8]. Surgical treatment options include insertion of a tympanic drain, myringotomy and adenoidectomy. The benefits of surgical treatment are questioned by two systematic reviews, as hearing difficulties virtually disappear spontaneously over time and the level of language and general development are equal in children with or without ventilation tubes $[9,10,11]$. We have barely found in the literature articles that link the diet to the development of OME. According to the line of research we have been developing, has been observed a large reduction in upper respiratory tract infections (URIs) and acute otitis media (AOM), when children followed a high-quality diet $[12,13]$. The objective of the study was to assess the effects of the traditional Mediterranean diet (TMD) on the evolution of otitis media with effusion.

\section{Materials and Methods}

\section{Study Design}

The design correspond to a prospective, before-following comparison analytical study in which all patients aged 1 to 5 years consecutively diagnosed with OME. The study was conducted at a primary care pediatrics consultation, during the period from September 2010 to December 2018. All parents or guardians gave informed consent. The intervention focused on a food re-education based on the TMD through the use of the nutrition education program "Learning to eat from the Mediterranean" which was used in previous studies [12,13]. This program consists of a series of visits with the nutritionist and the pediatrician, who proposed to assist the family. Visits are monthly 
for the first 4 months and bimonthly until the year is completed. The first visit evaluates the diet made by each child and his/her family, and changes in the usual diet are proposed making schemes, culinary recipes, example menus, etc. A baseline anthropometric assessment is also performed. Patients were monitored over the course of a year, valuing weight, stature, growth, clinical evolution, treatment needs, adherence to TMD and the degree of satisfaction of families. The study was approved by the Research Committee of the University General Hospital of Ciudad Real (Internal code: C-95, Act 03/2017).

\section{Measuring study parameters \\ 1.- Clinical parameters:}

The main variable was the presence of OME. Otitis media with effusion was considered when the bilateral exudate or effusion persisted for more than 3 months, or more than 6 if it is unilateral [14,15]. The presence of trans-tympanic fluid was assessed by otoscopy and with the help of a portable tympanometer (MicroTymp '3®). The following secondary variables were considered: number of upper respiratory tract infections (URI), number of episodes of OMA and rhino-sinusitis (RS), emergency assistance, number of symptomatic drugs and prescribed antibiotics, all of which are valued per person per year. A basic otorino-laryngological scan was done that included rhinoscopy, pharyngoscopy, otoscopy, tympanometry, audiometry in collaborating children with a portable audioscope (Audioscope $\left.{ }^{\circledR}\right)$, intentional face appreciation (adenoid facies) and cervical adenopathies and finally a clinical assessment was made of the degree of persistent nasal obstruction (PNO): mild-1, moderate-2, or severe- 3 . An episode of URI was defined by two or more of the following criteria: fever greater than 38o C measured with a tympanic thermometer, nasal congestion or oral breathing, nasal discharge, odynophagia and cough. AOM was defined according to the criteria of the Guide of the American Association of Pediatrics [16] are: 1. Acute presentation; 2. Presence of exudate in the middle ear cavity demonstrated by tympanic bulge, pathological or otorrhea pneumatoscopy; 3. Inflammatory signs and symptoms such as otalgia or evident redness of the eardrum. When the diagnosis of AOM was confirmed, conservative or expectant treatment was followed in mild cases and antibiotics were administered in cases of increased risk, such as in children under 2 years of age, bilateral AOMs, and those with increased general affectation. It was defined as rhino-sinusitis to the persistence of daytime or rhinosherhorrhone cough for more than ten days, with no apparent improvement, in the context of an upper respiratory infection [17]. Persistent nasal obstruction was defined as difficulty breathing properly nasally, with associated respiratory symptoms, such as oral breathing, snoring, difficult breathing in sleep, stopping respiratory sleep (apnea), agitated sleep, neck stresses to sleep, drowsiness or feeling of not having rested properly, adenoid facies and swallowing difficulties [18].

2.- Clinical and therapeutic evaluation rate performed on parents or guardians. To assess the clinical evolution of the patients, a questionnaire was designed, addressed to parents or guardians, in which the symptoms related to OME were evaluated and their subsequent evolution, the intensity of clinical tables, the needs of difficulties with 
the diet and, the degree of satisfaction with the intervention. To each question in the questionnaire, one can answer the improvement observed with: 3: much, 2: quite, 1: something, 0: nothing.

Ten questions referred to the clinic and treatment in the previous four weeks and a maximum of 30 (good control) to a minimum of 0 (poor control) was scored.

A patient was considered to be poorly controlled when the total score was equal to or less than 20. (Table 1)

Table 1. Clinical and therapeutic evaluation index. Responses from parents or guardians regarding the improvement observed: 3: much, 2: quite, 1: something, 0 : nothing.

\begin{tabular}{|l|l|l|}
\hline Clinical and therapeutic evaluation index & $\mathbf{4}^{\mathbf{0}}$ month & 1 Year \\
\hline $\begin{array}{l}\text { Has the number of highways colds } \\
\text { decreased? }\end{array}$ & 2.29 \\
\hline $\begin{array}{l}\text { Have you noticed less intensity in the } \\
\text { infectious processes? }\end{array}$ & 2.70 \\
\hline $\begin{array}{l}\text { Has the nasal obstruction decreased, } \\
\text { breathe better? }\end{array}$ & 2.96 \\
\hline $\begin{array}{l}\text { Have complications decreased? } \\
\text { Do you hear better? }\end{array}$ & 2.95 \\
\hline $\begin{array}{l}\text { Have you noticed the least use of } \\
\text { antibiotics? }\end{array}$ & 2.50 & 2.95 \\
\hline $\begin{array}{l}\text { Have you noticed the least use of } \\
\text { symptomatic medications? }\end{array}$ & 2.95 & 2.95 \\
\hline $\begin{array}{l}\text { Has there been good diet tolerance on the } \\
\text { part of the patient? }\end{array}$ & 2.95 & 2.95 \\
\hline Has food quality improved? & 2.96 & 2.96 \\
\hline Are you satisfied with the results? & & 2.96 \\
\hline
\end{tabular}

\section{3.- Weight-statutory evolution parameters.}

Anthropometric data were collected, such as weight, height, skin folds, perimeters of the arm, abdomen and waist according to standardized procedures and with them the body mass index, lean mass and body fat mass were calculated.

\section{4.- Parameters of accession to the TMD.}

Adherence to the diet was assessed using the Kidmed test, and the TMD test, which was discussed in previous works $[12,13,19]$.

The traditional Mediterranean diet is characterized by a high content of fresh, raw, perishable and seasonal foods, rich in vegetable fiber, minerals, vitamins, enzymes and anti-oxidants; Abundant fruits, vegetables, legumes, and whole grains, one of whose characteristics is its low-moderate glycemic index; Sufficient polyunsaturated fats from crude oils, nuts, seeds and fish; Low protein and saturated fat content of animal origin and, a low use of precooked and industrial foods. This means, in daily practice, the limitation of products such as white bread, industrial pastries, cow's milk, red and 
processed meats, sugary industrial beverages and precooked fast food [20]. The TMD is based on the Decalogue that the Foundation of the Mediterranean diet proposes to us through its website (Table 2) [21].

\section{Table 2: Mediterranean diet. 10 basic recommendations}

1- Use olive oil as your main source of added fat.

2- Eat plenty of fruits and vegetables; fruits, vegetables, legumes and nuts.

3- Bread and other grain products (pasta, rice, and whole grains) should be a part of your everyday diet.

4- Foods that have undergone minimal processing, that are fresh and locally produced are best.

5- Consume dairy products on a daily basis, mainly yogurt and cheese.

6- Red meat should be consumed in moderation and if possible as a part of stews and other recipes.

7- Consume fish abundantly and eggs in moderation.

8- Fresh fruit should be your everyday dessert and, sweets, cakes and dairy desserts should be consumed only on occasion.

9- Water is the beverage par excellence in the Mediterranean Diet.

10- Be physically active every day, since it is just as important as eating well.

This has been proclaimed cultural heritage and intangible heritage of humanity by Unesco [22]. In Table 3, we expose the differences between TMD and the diet promoted by "Western civilization".

\begin{tabular}{|c|c|}
\hline Traditiona & Vester \\
\hline 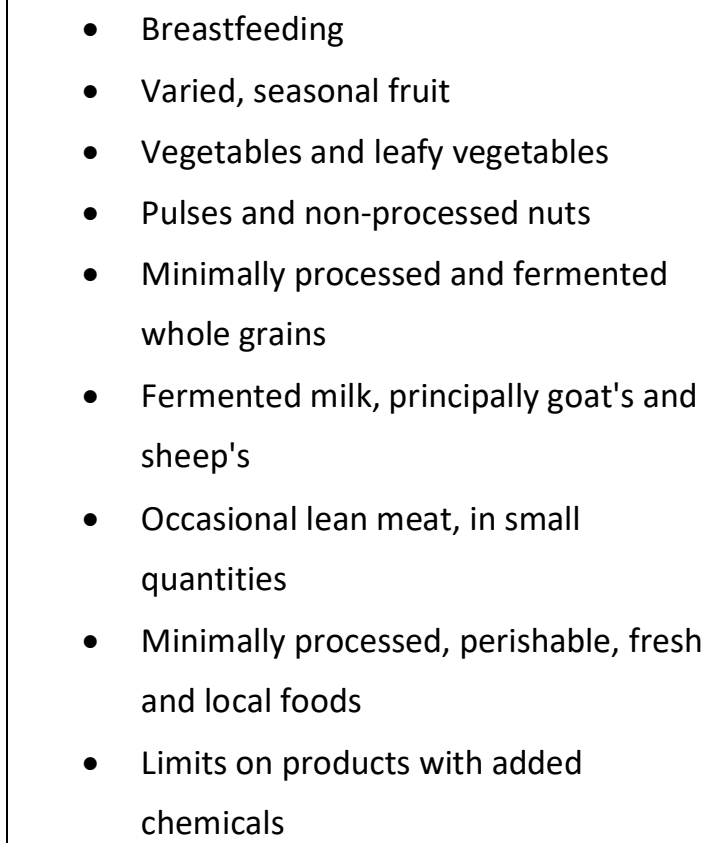 & $\begin{array}{l}\text { - } \text { Adapted milk } \\
\text { - Baby food jars and canned fruits } \\
\text { - } \text { Baby food jars and canned vegetables and } \\
\text { - Canned pulses and dried, fried or salted } \\
\text { - } \text { nuts } \\
\text { - } \text { Refined, processed cereals with industrial } \\
\text { - High consumpting agents } \\
\text { - Nonperishable processed red, processed meats } \\
\text { - ultra-processed foods } \\
\text { Presence of chemical agents and enzyme } \\
\text { disrupters }\end{array}$ \\
\hline
\end{tabular}


5.- Sample size and statistical analysis: To calculate the sample size, a significance level of 0.05 and a power of $80 \%$ was used, assuming an OME decrease of $50 \%$ and a standard deviation of 3.5 units, adjusting for a $25 \%$ loss, which resulted in a sample size of 80 patients. For the analysis of the results, the statistical package SPSS 15.0 was used. A descriptive analysis was carried out with statistics of central tendency and dispersion for quantitative variables, absolute and relative frequencies for qualitative variables. The comparison of the results of the different variables before and after the intervention was carried out by means of the Student's t-test for paired data when the variables followed a normal distribution, or by the Wilcoxon test when they did not adjust to normal, after checking with the Shapiro-Wilk test.

\section{Results}

It was proposed to participate in the program "Learning to eat from the Mediterranean", the families of 93 patients met the criteria of inclusion of OME, and 7 refused to participate. Of the 86 patients included, 6 left the program after the first sessions. Two for social or personal difficulties in implementing the diet, one by disagreement with the limitation of some foods and 3 for surgical intervention indicated by the OR service not coordinated with our team. The study thus completed a total of 80 patients ( 40 girls and 40 boys) with an average age of 3.1 years. All patients included in the study were evaluated at 4 and 12 months of the initial visit. The results obtained were similar in both sexes, so they are collected together (Table 4).

\begin{tabular}{|l|c|c|}
\hline \multicolumn{3}{|c|}{ Table 4. Sample characteristics. Average age 3,1 years } \\
\hline & Boys $(\mathbf{n}=\mathbf{4 0})$ & Girls $(\mathbf{n}=40)$ \\
\hline Weight $(\mathrm{kg})$ & $13.16 \pm 2.35$ & $15.00 \pm 2.21$ \\
\hline Height $(\mathrm{m})$ & $0.90 \pm 0.06$ & $0.95 \pm 0.07$ \\
\hline BMI $\left(\mathrm{kg} / \mathrm{m}^{2}\right)$ & $15.97 \pm 1.46$ & $16.42 \pm 1.19$ \\
\hline Fat mass $(\%)$ & $15.60 \pm 2.77$ & $14.89 \pm 1.95$ \\
\hline Lean mass $(\%)$ & $11.05 \pm 1.78$ & $12.76 \pm 2.17$ \\
\hline
\end{tabular}

During the year of treatment, there was a normalization of tympanometry and therefore a reduction of patients affected by OME of $85 \%$ of the participants, while the remaining $15 \%$ had improved their hearing and/or associated symptoms. The number of ITRS and bacterial complications also decreased (Table 5). 
Table 5. Evolution during the previous year and during the year of treatment.

\begin{tabular}{|l|c|c|c|}
\hline & $\begin{array}{l}\text { Previous year } \\
\text { to treatment }\end{array}$ & $\begin{array}{l}\text { One year } \\
\text { treatment }\end{array}$ & P \\
\hline $\begin{array}{l}\text { Otitis Media with effusion (OME) } \\
\begin{array}{l}\text { Degree of involvement of chronic obstruction of the } \\
\text { upper airway (OCVAS). 0: mild, 1: moderate, 2: } \\
\text { intense }\end{array}\end{array}$ & $1.92 \pm 0.27$ & $0.26 \pm 0.05$ & 0.001 \\
\hline $\begin{array}{l}\text { Number of upper respiratory tract infections (ITRS) } \\
\text { per child and year }\end{array}$ & $6.01 \pm 1.41$ & $2.52 \pm 0.37$ & 0.001 \\
\hline $\begin{array}{l}\text { Bacterial complications per child and year (Acute } \\
\text { otitis media and rhino-sinusitis) }\end{array}$ & $3.12 \pm 0.75$ & $1.08 \pm 0.06$ & 0.001 \\
\hline Number of emergency treatments per child and year & $1.90 \pm 0.76$ & $0.33 \pm 0.04$ & 0.001 \\
\hline Antibiotics per child and year & $3.71 \pm 0.37$ & $0.58 \pm 0.08$ & 0,001 \\
\hline \begin{tabular}{l} 
Symptomatic treatment per child and year \\
\hline
\end{tabular} & $7.13 \pm 0.96$ & $3.03 \pm 0.39$ & 0,001 \\
\hline
\end{tabular}

The level of household satisfaction was high as shown in the questionnaire for the improvement observed (Table 1). Anthropometric variables before, at 4 months and after the intervention, are set out in Table 6. In the determining parameters of growth and development, such as size and lean mass, there was an adequate, statistically significant increase. The average weight increase in the year prior to the study was 2.01 $\mathrm{kg}$, compared to $2.45 \mathrm{~kg}$ today and the average size increase was $6.6 \mathrm{~cm}$ compared to $7.30 \mathrm{~cm}$ today. Body mass index (BMI) decreased. The lean mass area of the arm increased, while the area of fat mass was decreased.

Table 6. Anthropometric assessment at the start, after 4 months and after one year

\begin{tabular}{|l|c|c|c|c|}
\hline & $\begin{array}{c}\text { At the start of } \\
\text { treatment }\end{array}$ & $\begin{array}{c}\mathbf{4} \text { months of } \\
\text { treatment }\end{array}$ & $\begin{array}{c}\text { Year of } \\
\text { treatment }\end{array}$ & $\mathbf{P}$ \\
\hline BMI (body mass index) & $16.19 \pm 1.41$ & $15.74 \pm 1.03$ & $15.45 \pm 1.34$ & 0,11 \\
\hline Fat mass (\%) & $15.23 \pm 2.69$ & $15.03 \pm 2.49$ & $14.76 \pm 2.29$ & 0,27 \\
\hline Lean mass (\%) & $11.79 \pm 2.29$ & $12.44 \pm 1.98$ & $13.82 \pm 2.08$ & 0,03 \\
\hline
\end{tabular}

Patients' dietary habits had also improved in the sample as a whole at the end of the program. Thus, an increase in the number of patients consuming fruits, vegetables, fish, whole grains and fermented dairy was observed; on the other hand, the percentage of patients who did not eat breakfast or have breakfast industrial pastries decreased, as did the proportion of those who consumed treats on a daily basis. According to this data, the average value of the Kidmed index evolved from a score considered medium-high at the beginning of the program to an optimal value at the end of the program (Table 7). 


\begin{tabular}{|l|c|c|c|}
\hline Table 7. KidMed Test (percentage) & $\begin{array}{c}\text { At the } \\
\text { start }\end{array}$ & $\begin{array}{c}\text { After 4 } \\
\text { months }\end{array}$ & $\begin{array}{c}\text { After one } \\
\text { year }\end{array}$ \\
\hline & 80 & 98 & 100 \\
\hline 1 piece of fruit per day & 29 & 74 & 88 \\
\hline $1+$ piece of fruit per day & 91 & 97 & 100 \\
\hline 1 vegetable per day & 17 & 42 & 71 \\
\hline Vegetables more than once per day & 88 & 98 & 98 \\
\hline Regularly eats fresh fish (2-3 times/week) & 28 & 5 & 2 \\
\hline Visits fast food rest. once or more per week & 92 & 98 & 98 \\
\hline Legumes 1-2 times/week & 98 & 100 & 100 \\
\hline Pasta and rice every week & 71 & 98 & 98 \\
\hline Cereal or deriv. for breakfast & 20 & 28 & 31 \\
\hline Regularly eats dried fruit and nuts & 100 & 100 & 100 \\
\hline Olive oil used at home & 6 & 3 & 2 \\
\hline No breakfast & 34 & 95 & 98 \\
\hline Dairy at breakfast & 100 & 100 & 98 \\
\hline Factory-baked goods for breakfast & 22 & 3 & 2 \\
\hline Two yoghurts or 40g cheese / day & & 8 & 3 \\
\hline Sweets and snacks every day & 34 & \\
\hline
\end{tabular}

The TMD test evolved, from levels considered to be low quality, to optimal levels, (table 8 and Figure 1).

\begin{tabular}{|l|c|c|c|}
\hline Table 6. TMD Test ( \%) & & & \\
\hline & Start & 4 months & Year \\
\hline Minimum 2 pieces of fruit every day. & 42.5 & 76.3 & 93.8 \\
\hline $\begin{array}{l}\text { Fresh vegetables at every meal, as a first course or as } \\
\text { part of the main course }\end{array}$ & 38.1 & 53.6 & 79.1 \\
\hline $\begin{array}{l}\text { Limited sugar intake (sweetened breakfast cereal, } \\
\text { sweetened yoghurts or milkshakes, cakes, soft drinks, } \\
\text { sugary biscuits, sweets, ice-cream, etc). }\end{array}$ & 6.3 & 72.5 & 76.2 \\
\hline $\begin{array}{l}\text { Sporadic use of potatoes (1-2 times/week) and preferably } \\
\text { not fried. }\end{array}$ & 23.2 & 76.2 & 84.9 \\
\hline $\begin{array}{l}\text { Legumes twice or more per week, not always with meat. } \\
\text { Regular intake of white fish, oily fish and seafood (1 -3 } \\
\text { times/week). }\end{array}$ & 70.1 & 73.5 & 93.1 \\
\hline $\begin{array}{l}\text { Preferably eats whole grains (whole wheat pasta, brown } \\
\text { fice, brown bread, etc., limiting the intake of refined }\end{array}$ & 15.5 & 58.9 & 81.9 \\
\hline
\end{tabular}




\begin{tabular}{|c|c|c|c|}
\hline Intake of seasonal, natural, fresh food. & 25.3 & 72.4 & 84.4 \\
\hline $\begin{array}{l}\text { Moderate to low intake of dairy produce: Preferably in } \\
\text { the form of natural yoghurt and goat's or sheep's cheese. }\end{array}$ & 14.6 & 66.5 & 86.4 \\
\hline Only lean processed meats, less than twice per week. & 16.9 & 63.3 & 83.4 \\
\hline Preferably white meat, less than 3 times per week (lean). & 25.5 & 73.4 & 87.8 \\
\hline $\begin{array}{l}\text { 30- } 50 \% \text { of the daily intake consists of raw food (fruit, } \\
\text { vegetables, virgin extra olive oil, freshly-squeezed fruit } \\
\text { juice, nuts, etc.) and semi-raw food (green vegetables) }\end{array}$ & 4.9 & 29.8 & 63.7 \\
\hline $\begin{array}{l}\text { Frequent intake of broths, soups, natural smoothies and } \\
\text { water }\end{array}$ & 43.3 & 68.9 & 68.9 \\
\hline $\begin{array}{l}\text { Intake of fats mainly from virgin extra olive oil and raw } \\
\text { nuts. Avoiding low quality industrial fats. }\end{array}$ & 36.4 & 78.9 & 91.2 \\
\hline Good quality breakfast and mid-morning meal & 27.3 & 63.1 & 79.1 \\
\hline $\begin{array}{l}\text { No snacking between meals, and a reasonable portion } \\
\text { size at meals }\end{array}$ & 28.7 & 65.4 & 88.2 \\
\hline $\begin{array}{l}\text { Adapts to the food made at home (family) and } \\
\text { alternatives not offered.- }\end{array}$ & 38.2 & 65.5 & 86.4 \\
\hline $\begin{array}{l}\text { Limits intake of additives, avoiding "junk" food }(<1 / \\
\text { week) }\end{array}$ & 75.6 & 83.6 & 82.7 \\
\hline $\begin{array}{l}\text { Regular physical exercise (running, playing, walking, } \\
\text { climbing, etc) or sport. }\end{array}$ & 68.2 & 73.3 & 82.3 \\
\hline $\begin{array}{l}\text { Mealtimes together, avoiding the television or other } \\
\text { technology }\end{array}$ & 67.9 & 78.7 & 96.4 \\
\hline
\end{tabular}

Figure 1. Evolution of quality of diet, measured using TMD Test.

\begin{tabular}{|l|l|l|}
\hline \\
Begin
\end{tabular}

\section{Discussion}


In view of the results, we can say that the Traditional Mediterranean Diet can help prevent and also control otitis media with effusion. We have been able to verify that children who have followed our dietary recommendations have improved the inflammatory response and the defensive capacity against the usual infectious diseases. The study shows that a high percentage of patients with OME evolved satisfactorily with the use of TMD, tympanometry normalized in $85 \%$ of children. A decrease in the number of recurrent respiratory tract infections and their most frequent complications was also observed. The degree of nasal obstruction (PNO) also decreased. In the remaining $15 \%$ of OME, although flat tympanometry persisted, their hearing and / or their symptoms improved. There was less use of symptomatic drugs, anti-inflammatory drugs and antibiotics. Emergency visits decreased and the degree of family satisfaction was high (Table 1). The number of URIs with bacterial complications decreased by $65 \%$ (3.12 from the previous year compared to 1.08 from the year of intervention). The average URI compared to the previous year was down $59 \% .62 \%$ of patients had no bacterial complications during the nutritional intervention period, $29 \%$ had only one in the whole year and $10 \%$ had two, compared to the 3 episodes they had on average in the previous year. Children with PNOs went from a mild-moderate to nothing-mild intensity profile. Emergency assistance also decreased by $70 \%$. Antibiotic use decreased by $84.3 \%$, and the use of symptomatic drugs decreased by $57.5 \%$. The majority of patients did not require surgical intervention, and clinical evolution suggests that it will no longer be necessary. This better way to defend against prevalent childhood diseases, together with the best anti-inflammatory response, could be the cause of the progressive decline in $\mathrm{PNO}$ in our pediatric population.

The main difficulty was the fulfillment of the diet, because they were proposed to make a homemade diet, family and fresh products that must be prepared and not always the parents had time and dedication to do it properly. The dietitian-nutritionist follow-up contest was essential to ensure compliance. By the end of the program, the dietary habits of the patients had improved in the sample as a whole: an increase in the number of patients consuming fruits, vegetables, nuts, whole grains and fermented dairy products was observed. In general, the consumption of proteins of animal origin was reduced considerably, especially cow's milk, red meats and meat products. The consumption of processed foods also decreased, especially industrial pastries. It is important to note that during the time that the incorporation of patients to the study lasted, we extended the application of TMD to the entire pediatric population (siblings, relatives, patients with other recurrent pathologies, and infants under two years of age). This led to a progressive decrease in patients diagnosed with OME, so the achievement of the sample size was delayed. All this has resulted in the decrease in patients diagnosed with OME and it begins to be a rare disease in children of our pediatric quota who follow TMD [23]. The growing interest in the Mediterranean diet is based on its role in inflammatory diseases [24]. Several clinical and epidemiological studies, as well as experimental studies show that the consumption of the DMT reduces the incidence of certain pathologies related to oxidative stress, chronic inflammation and 
the immune system such as cancer, atherosclerosis or cardiovascular disease [25]. There is evidence that diet and individual nutrients can influence systemic markers of immune function and inflammation [26]. There is, however, no data on its direct action in the pediatric patient. Some data suggest that the follow-up of a diet with an excess of refined flours and processed foods of animal origin, together with an infrequent consumption of fruits and vegetables, is associated with high inflammatory markers [27]. In studies conducted on mucoid samples of patients with OME, there was a global tendency to increase local pro-inflammatory mediators [28,29]. An increase in the markers of oxidative stress in the effusion of children with OME has also been demonstrated, which would lead to a pro-inflammatory and hyper-reactivity state of the mucosa against infectious agents $[30,31,32,33]$. In recent years, patients diagnosed with food intolerance to cow's milk proteins and other non-IgE-mediated foods, which cause inflammation in the digestive and respiratory mucous membranes with various symptoms, are increasing. The current treatment of these entities (food intolerances not mediated by IgE, eosinophilic esophagitis, sensitivity to non-celiac wheat, etc.) involves the elimination of the proteins involved $[34,35,36]$. We believe that sensitization to these proteins may be at the base of the inflammation of the mucosa of the middle ear and for this reason our patients could have responded adequately to their elimination in the diet. Data from several randomized clinic trials DM-based, have demonstrated a beneficial effect in de primary and secondary prevention of disease. The exact mechanism by which an increased adherence to the TMD exerts its favorable effects is not known, although they have been shown to protect against oxidative stress and inflammation [37].

On the other hand, the follow-up of the DMT is associated with a more beneficial microbiota profile for health, with a higher production of short chain fatty acids, the presence of Prevotella and some Firmicutes capable of degrading fiber [38]. Diet has a rapid effect on gut microbiota composition, which promotes the growth of certain bacterial groups over others, as well as changes in intestinal $\mathrm{pH}$, intestinal permeability, bacterial metabolites, and thus inflammation [39]. The available evidence, suggests that gut microbiota of subjects that follow the TMD is significantly different from subjects that follow a Western diet model. The latter show an increased gut permeability, which is responsible for metabolic endotoxemia. For this reason, we can speculate that the gut microbiota of the subjects following the TMD is able to prevent the onset of chronic non-communicable diseases [40]. The nasal microbial composition in children with OME is less diverse and with a greater abundance of pathogens than their peers without respiratory infections [41]. The changes in the levels of citocines, may indicate bacterial pathogen as one of the causes of OME [42]. The presence of Alloiococcus otitidis has been considered as a precipitating factor of OME [43]. Likewise, the importance of "bacterial biofilm" and its association with persistent otic disease has been observed $[44,45,46]$. Local administration of probiotic bacteria seems to have the ability to inhibit the growth of otopathogens [47]. It is interesting to consider the relationship of DMT with the nasopharyngeal microbiome and the role in the treatment or prevention of 
OME. The results of this intervention study would point to a possible mechanism of action.

One of the characteristics that every research study should have is that it is easily reproducible, using small groups, and with a little economic cost. Well, the work presented here is easy to reproduce in any primary care pediatric consultation, but it is not easy to perform, due to the lack of nutritionists and the lack of effective monitoring of the diet performed. Our study has limitations, in particular the lack of a control group, which would allow us to compare the results. It would have been very interesting to perform analyzes that measured the response of the immune system, inflammatory markers and data on the modification of the microbiota when making the nutritional change. The present study is only part of a general project that we are carrying out that covers most of the recurrent diseases of childhood. We believe that the diet proposed by the "Western civilization" is the origin of alterations in the inflammatory and immune mechanisms and therefore the cause of most childhood diseases. Most of our patients have been consecutively included in the program "Learning to eat from the Mediterranean" and as a result, the prevalence of OME and other recurrent diseases has decreased considerably. It should not go unnoticed, the change of "model of medicine" that these research studies entail. It is no longer about remedying a disease with external drugs, outside the defensive system or limiting surgical interventions, but the therapeutic proposal is based on providing the body with everything it needs to solve their needs and eliminate that for which it is not ready. We can conclude by saying that the application of the Traditional Mediterranean Diet has promising effects in the prevention and treatment of otitis media with effusion, with the normalization of tympanometry and hearing loss, with a notable decrease in associated inflammatory diseases, use of drugs and placement of grommets.

"This research received no external funding"

"The study was conducted ac-cording to the guidelines of the Declaration of Helsinki, and approved by the Institutional Review Board (or Ethics Committee) of Hospital General Universitario de Ciudad Real (Internal code: C-95, Act 03/2017)."

"Informed consent was obtained from all subjects involved in the study."

"The authors declare no conflict of inter-est."

\section{References}

1. Bluestone, C.D.; Gates, G.A.; Klein, J.O.; Lim, D.J.; Mogi, G. et al. Definitions, terminology, and classification of otitis media. The Annals of Otology, Rhinology and Laryngology 2002;111 Suppl:8-18. [Google Scholar] 
2. Mudry, A.; Young, J.R. Otitis media with effusion: Politzer's 100 year legacy. Int J Pediatr Otorhinolaryngol. 2020 Sep;136:110160. doi: 10.1016/j.ijporl.2020.110160. Epub 2020 Jun 3. PMID: 32544637. [Google Scholar]

3. Rosenfeld, R.M.; Shin, J.J.; Schwartz, S.R.;, Coggins, R.; Gagnon, L. et al. Clinical Practice Guideline: Otitis Media with Effusion (Update). Otolaryngol Head Neck Surg. 2016 Feb;154(1Suppl):S1-S41. doi: 10.1177/0194599815623467. [Google Scholar]

4. Welling, D.R.; Ukstins, C.A. Otitis Media: Beyond the Examining Room. Pediatr Clin North Am. 2018 Feb;65(1):105-123. doi: 10.1016/j.pcl.2017.08.024. [Google Scholar]

5. Núñez-Batalla, F.; Jáudenes-Casaubón, C.; Sequí-Canet, J.M.; Vivanco-Allende, A.; Zubicaray-Ugarteche, J. Diagnosis and treatment of otitis media with effusion: CODEPEH Recommendations. Acta Otorrinolaringol Esp. 2019 Jan-feb; 70 (1): 36-46. doi: 10.1016 / j.otorri.2017.07.004. [Google Scholar]

6. Griffin, G.H.; Flynn, C.; Bailey, R.E.; Schultz, J.K. Antihistamines and/or decongestants for otitis media with effusion (OME) in children. Cochrane Database Syst Rev. 2006 Oct 18;(4):CD003423. Review. Update in: Cochrane Database Syst Rev. 2011;(9):CD003423. [Google Scholar] [PubMed]

7. Simon, F.; Haggard, M.; Rosenfeld, R.M.; Jia, H.; Peer, S. et al. International consensus (ICON) on management of otitis media with effusion in children. Eur Ann Otorhinolaryngol Head Neck Dis. 2018 Feb;135(1S):S33-S39. doi: 10.1016/j.anorl.2017.11.009. [Google Scholar]

8. American Academy of Pediatrics. Clinical practice guideline: otitis media with effusion. Pediatrics. 2004;113;1412-1429. [Google Scholar] [PubMed]

9. Browning, G.; Rovers, M.; Williamson, I.; Lous, J.; Burton, M. Grommets (ventilation tubes) for hearing loss associated with otitis media with effusion in children. Cochrane Database of Systematic Reviews 2010 Issue 10. Art. No: CD001801. DOI: 10.1002/14651858. [Google Scholar] [pubMed]

10. Hellström, S.; Groth, A.; Jörgensen, F.; Pettersson, A.; Ryding, M. et al. Ventilation tube treatment: a systematic review of the literature. Otolaryngol Head Neck Surg. 2011 Sep; 3:383-95. [Google Scholar] _ [PubMed]

11. Steele, D.W.; Adam, G.P.; Di, M.; Halladay, C.H.; Balk, E.M.; Trikalinos, T.A. Effectiveness of Tympanostomy Tubes for Otitis Media: A Meta-analysis. Pediatrics. 2017 Jun;139(6). pii: e20170125. doi: 10.1542/peds.2017-0125. [Google Scholar] [PubMed]

12. Calatayud-Sáez, F.M.; Calatayud, B.; Gallego, J.G.; González-Martín, C.; Alguacil, L.F. Mediterranean diet and childhood asthma. Allergologia et immunophatologia. Vol. 44. Núm. 02. Marzo-Abril 2016. [Google Scholar] [PubMed]

13. Calatayud, F.M.; Calatayud, B.; Gallego, J.G.; González-Martín, C.; Alguacil, L.F. Effects of Mediterranean diet in patients with recurring colds and frequent complications. Allergol Immunopathol (Madr). 2017 Sep Oct;45(5):417-424. doi: 10.1016/j.aller.2016.08.006. [Google Scholar] [PubMed]

14. Heidemann, C.H.; Lous, J.; Berg, J.; Christensen, J.J.; Håkonsen, S.J.; Jakobsen, M. et al. Danish guidelines on management of otitis media in preschool children. Int J Pediatr Otorhinolaryngol. 2016 Aug;87:154-63. doi: 10.1016/j.ijporl.2016.06.003. Epub 2016 Jun 7. [Google Scholar] [PubMed] 
15. Ito, M.; Takahashi, H.; Lino, Y.; Kojima, H.; Hashimoto, S.; Kamide, Y.; et al. Clinical practice guidelines for the diagnosis and management of otitis media with effusion (OME) in children in Japan, 2015. Auris Nasus Larynx, Volume 44, Issue 5, 2017, pp. 501-508. [Google Scholar] [PubMed]

16. American Academy of Pediatrics and American Academy of Family Physicians. Diagnosis and management of acute otitis media. Pediatrics. 2004;113:1451-65. [Google Scholar]

17. Martínez-Campos, L.; Albañil, J.; De la Flor, R.; Piñero, J.; Cervera, F.; Baquero, S. Consensus document on the aetiologyy diagnosis and treatment of sinusitis. An Pediat. Volume 79. Issue 5, Nov 2013, Pages 330.e1-330.e12. [Google Scholar]

18. Alonso-Álvarez, M.L. et al. Consensus document on sleep apnea-hypopnea syndrome in children. Arch Bronconeumol. 2011, 47(Supl 5): 2-18. [Google Scholar]

19. Calatayud-Sáez, F.M.; Calatayud, B. Efficacy of the recommendation of a Mediterranean diet pattern in preschoolers with overweight and obesity. Acta Pediátr Esp. 2020; 78(3-4):e101-e110 [Google Scholar]

20. Márquez-Sandoval, F.; Bulló, M.; Vizmanos, B.; Casas-Agustench, P.; Salas-Salvadó, J. A healthy eating pattern: the traditional Mediterranean diet. Antropo2008, 16, 11-22. [Google Scholar]

21. Foundation of the Mediterranean diet. 10 basic recommendations of the Mediterranean Diet. [Google Scholar]

22. WHO. Overweight and obesity. Geneva, Switzerland: World Health Organization, 2006. [Google Scholar]

23. Calatayud-Sáez, F.M.; Calatayud, B.; Luque, M.; Calatayud, A.; Gallego, J.G.; Rivas, F.

Effects of affinity to the Mediterranean Diet pattern along with breastfeeding on

childhood asthma, inflammatory and recurrent diseases in an intervention study. 2021.

Preprit, pending review. [Google Scholar] https://doi.org/10.22541/au. 160645686.65335832

$\measuredangle \mathrm{v} 1$

24. Tsigalou, C.; Konstantinidis, T.; Paraschaki, A.; Stavropoulou, E.; Voidarou, C.; Bezirtzoglou, E. Mediterranean Diet as a Tool to Combat Inflammation and Chronic Diseases. An Overview. Biomedicines. 2020;8(7):201. Published 2020 Jul 8. doi:10.3390/biomedicines8070201. [Google Scholar]

25. Casas, R.; Estruch, R.; Sacanella, E. The Protective Effects of Extra Virgin Olive Oil on Immune-mediated Inflammatory Responses. Endocr Metab Immune Disord Drug Targets. 2018;18(1):23-35. doi: 10.2174/1871530317666171114115632. [Google Scholar]

26. Venter, C.; Eyerich, S.; Sarin, T.; Klatt, K.C. Nutrition and the Immune System: A Complicated Tango. Nutrients. 2020; 12(3):818. [Google Scholar]

27. González-Gil, E.M.; Tognon, G; Lissner, L.; Intemann, T.; Pala, V.; Galli, C. et IDEFICS Consortium. Prospective associations between dietary patterns and high sensitivity C-reactive protein in European children: the IDEFICS study. Eur J Nutr. 2018;57(4):1397-1407. doi: 10.1007/s00394-017-1419-x. [Google Scholar]

28. Val, S.; Poley, M.; Anna, K.; Nino, G.; Brown, K.; Pérez-Losada, M. et al. Characterization of mucoid and serous middle ear effusions from patients with chronic otitismedia: implication of different biological mechanisms? Pediatr Res. 2018 Aug;84(2):296-305. doi: 10.1038/s41390-018-0060-6. [Google Scholar] 
29. Li, Z.H.; Fu, Q.Y.; Li, Z.Y.; Wang, K.X.; Xu, Y.C.; Xue, J.P._The role of Th1/Th2 cells imbalance in the pathogenesis of secretory otitis media. Journal of Clinical Otorhinolaryngology, Head, and Neck Surgery. 2018, Feb;32(3):206-208] doi: 10.13201 / j.issn.1001-1781.2018.03.012. [PubMed]

30. Kang, D.W.; Dong, S.H.; Kim, S.H.; Kim, Y.I.; Park, D.C.; Yeo, S.G. Expression of endoplasmic reticulum stress-related mRNA in otitis media with effusion. Int J Pediatr Otorhinolaryngol. 2019 Mar;9;121:109-113. doi: 10.1016/j.ijporl.2019.03.006. [Google Scholar]

31. Şimşek, E.; Bicer, C.K.; Mazlumoğlu, M.R.; Kara, S.S.; Erel, O.; Çarlıoğlu, A. Am J Otolaryngol. Is otitis media with effusion associated with oxidative stress? Evaluation of thiol/disulfide homeostasis. Am J Otolaryngol. 2019 Mar - Apr;40(2):164-167. doi: 10.1016/j.amjoto.2018.12.012. [Google Scholar]

32. Tosti, V.; Bertozzi, B.; Fontana, L. Health Benefits of the Mediterranean Diet: Metabolic and Molecular Mechanisms, The Journals of Gerontology: Series A, Volume 73, Issue 3, March 2018, Pages 318-326. [Google Scholar]

33. Sagiroglu, S.; Ates, S.; Tolun, F.I.; Oztarakci, H. Evaluation of oxidative stress and antioxidants effect on turning process acute otitis media to chronic otitis media with effusion. Niger I Clin Pract. 2019 Mar;22(3):375-379. doi: 10.4103/njcp.njcp_126_18. [Google Scholar] [PubMed]

34. Lucendo, A.J.; Molina-Infante, J.; Arias, A.; von Arnim, U.; Bredenoord, A.J.; Bussmann, C. et al. Guidelines on eosinophilic esophagitis: evidence-based statements and recommendations for diagnosis and management in children and adults. United European Gastroenterology Journal. 2017; 5: 335-58. [Google Scholar] [PubMed]

35. Espín-Jaime, B. et al. Alergia a las proteínas de leche de vaca no mediada por IgE: documento de consenso de la Sociedad Espanola de Gastroenterología, Hepatología y Nutrición Pediátrica (SEGHNP), .... An Pediatr (Barc). 2018. [Google Scholar]

36. Catassi, C.; Alaedini, A.; Bojarski, C.; Bonaz, B.; Bouma, G.; Carroccio, A.; et al. The Overlapping Area of Non-Celiac Gluten Sensitivity (NCGS) and Wheat-Sensitive Irritable Bowel Syndrome (IBS): An Update. Nutrients. 2017; 9: pii: E1268. doi: 10.3390/nu9111268. [Google Scholar]

37. García-Montero, C.; Fraile-Martínez, O.; Gómez-Lahoz, A.M.; Pekarek, L.; Castellanos, A.J.; Noguerales-Fraguas, F. et al. Nutritional Components in Western Diet Versus Mediterranean Diet at the Gut Microbiota-Immune System Interplay. Implications for Health and Disease. Nutrients. 2021; 13(2):699. [Google Scholar]

38. De Filippis, F.; Pellegrini, N.; Vannini, L.; Jeffery, I.B.; La Storia, A.; Laghi, L. et al. High-level adherence to a Mediterranean diet beneficially impacts the gut microbiota and associated metabolome. Gut. 2016 Nov;65(11):1812-1821. doi: 10.1136/gutjnl-2015-309957. [Google Scholar] [PubMed]

39. Kolbe, A.R.;, Castro-Nallar, E.; Preciado, D.; Pérez-Losada, M. Altered Middle Ear Microbiome in Children With Chronic Otitis Media With Effusion and Respiratory Illnesses. Front Cell Infect Microbiol. 2019 Oct;4;9:339. doi: 10.3389/fcimb.2019.00339. [Google Scholar]

40. Merra, G.; Noce, A.; Marrone, G.; Cintoni, M.; Tarsitano, M.G.; Capacci, A.; De Lorenzo, A. Influence of Mediterranean Diet on Human Gut Microbiota. Nutrients. 2021; 13(1):7. [Google Scholar] 
41. Walker, R.E.; Walker, C.G.; Camargo, C.A.; Jr, Bartley, J.; Flint, D.; Thompson J.M.D.; Mitchell, E.A. Nasal microbial composition and chronic otitis media with effusion: A case-control study. PLoS One. 2019 Feb;22;14(2):e0212473. doi: 10.1371/journal.pone.0212473. [Google Scholar]

42. Zelazowska-Rutkowska, B.; Skotnicka, B.; Cylwik, B. Vascular endothelial growth factor and transforming growth factor $\beta$ in hypertrophic adenoids in children suffering from otitis media with effusion. Cytokine. 2020 Sep;133:155125. doi: 10.1016/j.cyto.2020.155125. Epub 2020 May 18. PMID: 32438279. [Google Scholar] [PubMed]

43. Korona-Glowniak, I.; Wisniewska, A.; Juda, M.; Kielbik, K.; Niedzielska, G.; Malm, A. Bacterial aetiology of chronic otitis media with effusion in children - risk factors. J Otolaryngol Head Neck Surg. 2020 Apr 29;49(1):24. doi: 10.1186/s40463-020-00418-5. PMID: 32349795; PMCID: PMC7191732. [Google Scholar]

44. Kania, R.; Vironneau, P.; Dang, H.; Bercot, B.; Cambau, E.; Verillaud, B. et al . Bacterial biofilm in adenoids of children with chronic otitis media. Part I: a case control study of prevalence of biofilms in adenoids, risk factors and middle ear biofilms. Acta Otolaryngol. 2019 Feb;26:1-6. doi: 0.1080/00016489.2019.1571282. [Google Scholar] [PubMed]

45. Elzayat, S.; Nosair, N.; Ghazy, A.A.; Abdulghaffar, I.A. Otitis media with effusion is not a sterile inflammatory process: scanning electron microscope evidence. Eur Arch Otorhinolaryngol. 2020 Sep 5. doi: 10.1007/s00405-020-06338-4. Epub ahead of print. PMID: 32889624. [Google Scholar] [PubMed]

46. Hamilos, D.L. Biofilm Formations in Pediatric Respiratory Tract Infection: Part 1: Biofilm Structure, Role of Innate Immunity in Protection Against and Response to Biofilm, Methods of Biofilm Detection, Pediatric Respiratory Tract Diseases Associated with Mucosal Biofilm Formation. Curr Infect Dis Rep. 2019 Feb;28;21(2):6. doi: 10.1007/s11908-019-0658-9. [Google Scholar]

47. Coleman, A.; Cervin, A. Probiotics in the treatment of otitis media. The past, the present and the future. Int J Pediatr Otorhinolaryngol. 2019 Jan;116:135-140. doi: 10.1016/j.ijporl.2018.10.023. Epub 2018 Oct 19. [Google Scholar] [PubMed] 